\title{
A Review on Remote Sensing and GIS Applications in Soil Resource Management
}

\author{
V. Arunkumar*, M. Pandiyan and M. Yuvaraj \\ Agricultural College and Research Institute, Vazhavachanure, Tamil Nadu, India \\ *Corresponding author
}

\section{A B S T R A C T}

\begin{tabular}{|l|}
\hline Ke y w o r d s \\
$\begin{array}{l}\text { Planning strategies, } \\
\text { land management, } \\
\text { highly expensive } \\
\text { process }\end{array}$ \\
\hline Article Info \\
\hline $\begin{array}{l}\text { Accepted: } \\
\text { 10 April } 2020 \\
\text { Available Online: } \\
\text { 10 May } 2020\end{array}$ \\
\hline
\end{tabular}

Planning strategies for sustainable land management require solid base line data on natural resources (soils, physiography, climate, vegetation, land use, etc.) and on socio-economic aspects. Extensive and reliable information on soil and land resources are prerequisites for efficient and effective management planning of these vital natural resources. Generation of large-scale spatial database on soil and land resources by conventional method is a time consuming and highly expensive process. The application of Remote sensing technology has been universally recognized as a highly effective and inevitable tool for soil resource mapping and watershed management.

\section{Introduction}

The modern tools of Remote Sensing (RS) and Geographic Information System (GIS), and Satellite based positioning systems (popularly called GPS) are appropriate for natural resources assessment and management. RS is the acquisition of information about an object, a phenomena or a process by noncontact method, usually from airplanes or satellites, using sensors operating in any portion of the electromagnetic spectrum. The GIS allows inputting, management, analysis and display of the data collected by RS and other means. GPS instruments are used to obtain precise measurement of an object's location in terms of longitude, latitude and altitude.

At global scale these technologies provide a cost effective means to study the biosphere, geosphere and atmospheric interactions. At micro scale, space technology is providing valuable inputs for developing land and water resources. Monitoring of changes in the forest cover using RS and drafting developmental 
plans for afforestation using GIS are good examples of macro and micro-level applications. ${ }^{1,2,3}$

The availability of remotely sensed data from different sensors of various platforms with a wide range of spatiotemporal, radiometric and spectral resolutions has made remote sensing as, perhaps, the best source of data for large scale applications and study. The exhaustive data provided by remote sensing is now serves as an input data for several environmental process modeling. ${ }^{4,5}$ The characterization and classification of soil resources in Palar-Manimuthar watershed of Tamil Nadu played a crucial role in optimal utilization of natural resources on a sustained basis. ${ }^{6,7}$

\section{Concepts of soil in soil resource mapping soil}

Soil is three dimensional, natural body, modified by man of earth materials, containing living matter and capable of supporting plants out -of -doors. The upper limit is air or shallow water. Lower limit is normally hard rock or earthy materials visually devoid of biological activity.

\section{Pedon}

It is the smallest body of one kind of soil, hexagonal in shape which considers volume of soil. Surface is roughly polygonal and ranges from $1 \mathrm{~m}^{2}$ to $10 \mathrm{~m}^{2}$ in area, depending upon the nature and variability of soil.

\section{Profile}

It is the vertical section of pedon showing the nature and arrangement of horizons. In soil resource inventories soil horizons are normally examined and described through profiles. It is the unit of sampling within a pedon. Profiles are examined upto $2 \mathrm{~m}$ or bedrock whichever is shallow.

\section{Polypedon}

It consists of several pedons of similar in nature. It is also inferred soil individual or soil series. It is the unit of soil mapping and classification.

\section{Mapping unit}

It is the collection of areas defined and named the same in terms of soil series / soil association / types and phases of soil series. Each map unit differs in some respect from other areas identified on a soil map. Each individual areas on the map is a delineation.

\section{Taxonomic unit}

The taxonomic unit aimed for classifying the soils above the level of soil series based on diagnostic horizons, soil temperature and moisture regimes, and particle size and mineralogical classes in the control section. It mostly considers the soil properties between $25 \mathrm{~cm}$ and $100 \mathrm{~cm}$ depth. Taxonomic unit are order, suborder, great group, subgroup and family.

\section{Base maps}

These are maps used for delineations of soil boundaries. For traditional soil surveys, base maps are toposheets and village maps. In modern surveys, base maps generated from aerial photographs and satellite data (Photograhpic / digital) are employed.

\section{Standard soil survey}

Standard soils survey is basically aimed at studying and recording the morphological characteristics of soils in the field and their physical and chemical properties in the laboratory, classifying them into well-defined 
units a delineating their boundaries on standard scale of maps. Three types of soil surveys are distinguished based on the scale of base map, intensity of soil observation and precision mapping.

\section{Soil resource data}

\section{Site characteristics}

Geology, geomorphology, drainage, slope, erosion, land use, natural vegetation, depth of ground water table, stoniness, gravelliness, presence or absence of salinity and alkalinity.

\section{Morphological properties}

Horizon thickness, colour, mottles, texture, structure, calcareousness, concretions, abundance and size of roots and pores, permeability, presencec of clay films/ slicken sides.

\section{Analytical properties horizon wise (Table 2)}

\section{Use of aerial photograph in soil mapping}

Among the different aerial photograph, black and white, colour infra-red (IR) and colour Infra-red (CIR) aerial photographs are used in soil mapping. Aerial photographs with a scale of 1: 40,000 to 1: 60,000 for reconnaissance soil mapping and 1: 10,000 to 1: 25, 000 for detailed soil mapping are used. Aerial photographs permit 3D view through stereoscopes and hence slope, drainage pattern, natural features like hills, valleys and plains can be easily distinguished in a given geological formation. Sub divisions of landform (hlls, pediment, pediplain valley, alluvial plain etc) can be delineated using photo elements (slope, erosion, tone, texture, density of reservation, land use etc.) Physiographic units for each land form are identified. The physiographic units are studied in detail for the soil composition.
The steps involved the use of aerial photography for soil mapping is given in figure 1. Orthorectifiction has to be done if rectified aerial photograph are not used in soil mapping.

\section{Use of satellite data for soil mapping}

Satellite imageries (Photographic format) and digital data are used for soil mapping. Satellite imageries are available in 1:1 million, 1: 250,000, 1: 50,000 and 1: 25,000 scales are available for generating soil maps for different levels of planning. Summer season FCC are preferable for soil mapping. PAN merged LISS imageries are engaged in detailed soil mapping. Just like the aerial remote sensing, major land forms are delineated first by using image interpretation elements like texture, tone, shape, size, association and pattern through light table. Image interpretation units are identified. The soil composition for each image interpretation unit is then identified through field work followed by soil analysis (Figure 2).

Digital image processing using supervised classification and unsupervised classification under maximum likelihood function are employed for soil mapping. In supervised classification, training sets (cluster of pixels with known composition after field work) are engaged in generation of soil maps. In case of unsupervised classification, cluster map showing the pixels with similar digital number (DN) is prepared. Field work to assess the soil composition is carried for each cluster. This ground truth information is then fed into the computer to generate soil maps. ${ }^{8,9}$

\section{Soil maps}

Soil survey maps: Maps generated out of standard soil surveys using toposheets, village maps, aerial photographic or satellite data are published with suitable 
scales, after needed rectification processes.

Generalized soil maps: These are maps made by combining the delineation of existing soil survey maps to form broader map units by cartographic methods.

Schematic soil maps: Schematic soil maps are compiled at small scale $(1: 1 \mathrm{M}$ and above) from the existing maps like geology, geomorphology, climate, land use etc. with limited field investigations. These maps are useful in under developed regions in advance of organized field survey.

Digital soil maps: These maps are generated from the existing soil maps after scanning and digitization by using ground control points. Digital soil maps are used as a layer of information from generating other thematic maps either by manual GIS or computer based GIS.

Thematic maps: These maps are developed for different application processes by using GIS. eg. Soil suitability maps, soil quality map etc.

The choice of method for soil resource mapping involving the preparation of base maps using remote sensing tools like aerial photographs and satellite data depend upon maximum power, finance and time. Remote sensing methods are preferable than the conventional methods as they save time and money. Based on the past soil surveys conducted in various projects, the following methods are suggested for different surveys.

\section{Application / interpretation of soil maps}

Soil maps are used various applications depending upon the situations and the different applications are given as follows.

\section{Land capability classification}

Land capability classification is an interpretative grouping of soils mainly based on inherent soil characteristics, external land features and environmental factors that limit the use of land for agriculture. There are eight land capability classes designated by Roman letters I to VIII in the increasing order of hazards and limitation in the use of land. Class I to IV are suitable for agriculture under proper and specific management. Classes $\mathrm{V}$ to VIII is suited only for wildlife sanctuary and recreational purposes.

Land capability subclasses are soil groups within a land capability class that are designated by small letters like 'e' for erosion, ' $\mathrm{s}$ ' for soil limitations and ' $c$ ' for climatic limitations ' $w$ ' for wetness. Land capability units are grouping of one or more soil mapping units having similar potentials and continuing limitation and hazards.

\section{Land irrigability classification}

Land Irrigability classification is concerned with predicting the behaviour of soils under the greatly altered water regime brought about by the introduction of irrigation. This is done based on soil irrigability classes (A to E), topography and drainage. Arabic numbers 1 to 6 indicates land irrigability classes. Limitations increase with increasing number of land irrigability class. Classes 1 to 4 are suitable for irrigation. Class 5 is temporarily classified for unsuitable for irrigation pending further investigations. Class 6 includes lands permanently unsuitable for irrigation.

Land irrigability subclasses are the lands that have the same kinds of limitations for sustained use under irrigation. Lower case letters "s", " $\mathrm{t}$ " and "d" are used to show whether the deficiency is due to soil properties or topography or drainage.

Lands with more than one major deficiency are indicated with the relevant letters after the irrigabilty class. 


\section{Fertility capability classification}

This is a technical system of grouping soils according their fertility constraints in a qualifiable manner. The physical and chemical properties of the soil are considered for Fertility Capability Classification. This system helps in grouping the soils with the same kind of fertility limitations and fertilizer response. Type, substrata type and condition modifiers form the soil fertility capability classification. Type is determined by the surface texture of soil (C,L,S,O). Substrata Type refers to the texture of the subsoil between 20 and $50 \mathrm{~cm}$ depth (C,L,S,R) condition modifiers indicate the physical and chemical properties of the soil that influence the soil and fertilizer interactions. The modifiers are ; g (gleying), d (dry), e (Low CEC), a (aluminium toxicity, $\mathrm{h}$ (acid condition), i (Fe-p fixation), x (X-ray amorphous), $\mathrm{v}$ ( Vertic characteristics), $\mathrm{k}$ (K deficiency), b (basic reaction) s ( salinity), $n$ ( nitric) and c (cat clay).

\section{Land suitability classification}

Land suitability classification refers to the fitness of a given type of land for a defined use. Suitability classification is arrived at on the basis of soil survey information, economic and social analysis, kinds of land use and the need for the change. Separate classifications are made with respect to each kind of land use that appears to be relevant for the area. ${ }^{10}$ The categories recognized in land suitability classification are order, classes, subclasses and units. There are two orders viz., suitable (S) and non-suitable $(\mathrm{N})$. The classes distinguished are S1- highly suitable, S-2 moderately suitable and S-3 marginally suitable. The sub-classes reflect kinds of limitation as in land capability sub-casses. The suitability units in a sub-class differ in management requirements. Depending upon the purpose, scale and intensity of study, either all or limited number of categories may be adopted.

Soil suitability models for specific crops are dependent upon the suitability criteria of soil site characters under the existing management conditions. Since the suitability of a soil to the crop is determined on the limiting characteristics, the suitability of a soil with respect to a crop might be underestimated. ${ }^{11}$

\section{Soil productivity rating}

To evolved a system of soil appraisal in terms of actual and potential productivity. It is a modified version of Storie Index. Eight factors viz., moisture (H), drainage (D), depth $(\mathrm{P})$, texture / structure (T), base saturation $(\mathrm{N})$, soluble salt content $(\mathrm{S})$, organic matter $(\mathrm{O})$ and mineral reserves $(\mathrm{A})$ are rated on a scale of $0-100$ and the percentages cumulatively multiplied to obtain productivity index $(\mathrm{P})$. In a similar manner the potentiality index $(\mathrm{P})$ is calculated after affecting the management measures. The ratio of $\mathrm{P}^{\prime}$ : $\mathrm{P}$ indicating the extent to which productivity can be improved, is called the co-efficient of improvement (CI). ${ }^{12}$

$\mathrm{P}$ (or) $\mathrm{P}^{`}=\mathrm{H} / 100 \times \mathrm{D} / 100 \times \mathrm{P} / 100 \times \mathrm{T} / 100$ $x \mathrm{~N} / 100 \times \mathrm{S} / 100 \times \mathrm{O} / 100 \times \mathrm{A} / 100 \times 100$

Co-efficient of Improvement $(\mathrm{CI})=\mathrm{P} / \mathrm{P}$

Soils with rating index 65-100 are excellent, 35-64 is good, 20-34 is average and 8-19 is poor and below 8 is extremely poor. Maps showing productivity and potentiality index can be prepared. The productivity ratings help in choosing the best land use options among field, fodder and tree crops. Suppose the productivity rating of a soil unit for field, fodder and tree crops is 60,80 and 50 then it can be constructed that the soil has the most production potential for fodder crops than for trees or field crops. 


\section{Soil quality maps}

These maps are derived from existing soil maps for different soil parameters like depth, erosion, texture, bulk density, $\mathrm{pH}, \mathrm{EC}$, organic matter, CEC, BSP etc. these maps in land management practices. For example, $\mathrm{pH}$ maps can be used for crop selection and land reclamation practices like liming in acid soil and application of gypsum in alkali soil.

\section{Remote sensing and GIS in watershed characterization and management}

Watershed is a natural hydrologic entity governed by the terrain topography from where run-off is drained to a point. The term watershed is a general term, thus its size and area depends on the scale of the base map used for delineation and codification. Multispatial resolutions satellite data along with topographic drainage maps of varying scales can be effectively utilized for delineation of various levels of watershed. Stereo aerial photograph and satellite remote sensing data are also very useful for delineation for watershed. Digital Elevation Model (DEM) derived by processing of topographic contour information in GIS environment can be used for automated delineation of ridgelines and drainage network through specialized analysis. Various watershed characteristics except socio-economic conditions/status can be obtained by using satellite remote sensing and GIS techniques, directly or indirectly. Watershed characteristics can be broadly divided into (a) Topographic characteristics, (b) Geologic characteristics (c) soils (d) vegetation \& land use (e) climatic and (f) socio-economic characteristics.

\section{Watershed prioritization}

Watershed Prioritization is a prerequisite to operationalize any major scheme, as it allows the planners and policy makers to adopt a selective approach considering the vastness of the catchment area, severity of the problems, constraints of funds and manpower, demands of the local and political system. The prioritization of watersheds varies with the objectives of different schemes, but the basic framework of watershed remains same. Several quantitative erosional soil loss estimation models used for prioritization of watershed based on weighted average erosion soil loss estimate watershed-wise.

\section{Remote sensing and GIS in soil erosion modeling}

Soil erosion prediction and assessment has been challenge to researchers since the 1930s' and several models have been developed. These models are categorized as empirical, semi-empirical and physical process-based models. Empirical models (e.g. USLE) are primarily based on observation and are usually statistical in nature. Semi-empirical models (e.g. MUSLE, MMF) lies somewhere between physically process-based models and empirical models and are based on spatially lumped forms of water and sediment continuity equations. Physical process-based models (e.g WEPP) are intended to represent the essential mechanism controlling erosion. They represent the synthesis of the individual components which effect erosion, including the complex interactions between various factors and their spatial and temporal variabilities.

\section{Universal soil loss equation (USLE)}

The USLE is the most widely used empirical overland flow or sheet-rill erosion equation (Wischmeir and Smith, 1978).

The equation was developed to predict soil erosion from cropland on a hillslope. The equation is given by,

A= R.K.L.S.C.P 
Where, A is the average annual soil loss (mass/area/year); $\mathrm{R}$ is the rainfall erosivity index; $\mathrm{K}$ is the soil erodibility factor; $\mathrm{L}$ is the slope length factor, $\mathrm{S}$ is the slope gradient factor; $\mathrm{C}$ is the vegetation cover factor and $\mathrm{P}$ is the conservation protection factor.

\section{Modified universal soil loss equation (MUSLE)}

The modified version of USLE that can be proposed by. ${ }^{13}$

Sye $=$ Xe.K.L.S.Ce.Pe

Where Sye is the event sediment yield

$\mathrm{Xe}=(\mathrm{Q}, \mathrm{qp}) 0.56$

Where 0.56 is an empirical co-efficient; Qe is the runoff amount and qp is the peak run-off rate obtained during the erosion and K.L.S.Ce $\&$ Pe as defined for USLE.

\section{Morgan, Morgan and Finney (MMF) model}

The model to predict annual soil loss, whilst endeavoring to retain the simplicity of USLE encompasses some of the recent advances in understanding of erosion process into a water phase and sediment phase. The model uses six operating equations for which 15 input parameters are required. The model compares predictions of detachment by rain splash and the transport capacity of the runoff and assessing the lower of the two values as the annual rate of soil loss, thereby denoting whether detachment or transport is the limiting factor. ${ }^{14}$

\section{Physical process based model}

Empirical models have constraints of applicability limited to ecological conditions similar to those from which data were used in their development. Further, USLE cannot deal with deposition; its applicability limits large areas and watersheds. Based on these considerations, several process based models have been developed (e.g WEPP, EUROSEM, LISEM. ${ }^{15}$

\section{Sediment yield index (SYI) model}

The AISLUS developed SYI model for prioritization of watershed in the catchment of River valley Project. ${ }^{16}$ It is predictive model based on the soil, land use and terrain slope characteristics. The potential utility of remotely sensed data in the form of aerial photographs and satellite sensors data have been, well recognized in mapping and assessing landscape attributes controlling soil erosion, such as physiography, soils, land use/land cover, relief, soil erosion pattern. Remote sensing can facilitate studying the factors enhancing the process, such as soil type, slope gradient, drainage, geology and land cover. Multi-temporal satellite images provide valuable information related to seasonal land use dynamics. Satellite data can be used for studying erosional features, such as gullies, rainfall interception by vegetation and vegetation cover factor. DEM (Digital Elevation Model) one of the vital inputs required for soil erosion modeling can be created by analysis of stereoscopic optical and microwave (SAR) remote sensing data.

Geographic Information System (GIS) has emerged as a power tool for handling spatial and non-spatial geo-referenced data for preparation and visualization of input and output, and for interaction with models. There is considerable potential for the use of GIS technology as an aid to the soil erosion inventory with reference to soil erosion modeling and erosion risk assessment. Erosional soil loss is most frequently assessed by USLE. 16 Several studies showed the potential utility of remote sensing and GIS 
techniques for quantitatively assessing erosional soil loss. ${ }^{17,18,19}$

\section{Digital database on soils}

Though voluminous data on soils in the form of maps and attributes (physical and chemical properties of soils, geographical location, lithology, current land uses etc.) is available with various organization, there is no organized digital database at state or national level available to concerned uses. It is therefore necessary to develop a centralized digital database.

The advent of Geographic information system (GIS), Relational Database Management System (RDBMS), Decision support system and rapid development of information technology (IT) have ushered a new discipline Soil Information System.

\section{Soil and terrain digital database (SOTER)}

The Soil and Terrain Digital Database provides an orderly arrangement of natural resource data in such a way that these data can be readily accessed, combined and analyzed from the point of view of potential use and production, in relation to food requirements, environmental impact and conservation.

Basic in the SOTER approach is the mapping of areas with a distinctive, often repetitive pattern of land form, morphology, slope, parent material and soils at 1:1 million scale (SOTER UNITS). Each SOTER unit is linked through a Geographic information system with a computerized database containing all available attributes on topography, landform and terrain, soils, climate, vegetation and land use.

National natural resource information system (NRIS)

The Department of Space, Govt, of India has developed National Natural Resource Information System (NRIS) for providing information to decision makers. It encompasses information on natural resources related to land, soil, water, forest etc. collected through remote sensing techniques and conventional resources and also information on socio-economic parameters.

NRIS is visualized as a network of GIS based notes covering the watershed or block, district, state and country, which include both spatial and non-spatial inputs. Feature coding scheme for every input element (including soil, watershed etc) has been worked out keeping in view the nationwide node work and natural hierarchy within feature classes for each of the theme.

\section{National informatics centre (NIC)}

The planning commission has been making many spatial database available on NICENET. GISNIC, the GIS software from NIC is being used for the development and retrieval of these databases. It is also being used as a presentation tool for preparing thematic maps for deriving the attribute information from the existing databases.

\section{Soil information system for soil health card (SISSHC)}

AISLUS has also developed a soil information system for soil health card. It has been suggested that soil health card should be introduced in all watershed management programme to generate awareness for better use of soil and land resources.

\section{Agricultural resource information system (AGRIS)}

The National Bureau of Soil Survey and Land Use Planning (NBSS\&LUP) has completed the soil resource mapping of different states of the country. The maps of 13 states have 
been prepared at a scale of 1:2, 50,000 and printed at a scale of 1:5000,000. In the course of soil resource studies done as $10 \mathrm{~km}$ interval, a voluminous soil information both at the field and through laboratory analysis have been generated.

The number of soil profile studies was of the order of about 75000 . The soil information is also stored in digital format. Dissemination of vast information on resources in various models is very much needed so that this could be utilized successfully by the planners and development agencies and for environment improvement. The NBSS\&LUP has identified as a sub-centre of Agricultural Research Information centre (ARIC) set up by ICAR for input to AGRIS covering soil science literature.

\section{Recent advances: hyper spectral remote sensing}

Conventional broad band sensors such as SPOT, Landsat MSS, IRS LISS III, LISS IV are not suitable for mapping soil properties because of their bandwidth of 100 to $200 \mu \mathrm{m}$ cannot resolve diagnostic features of terrestrial materials. Hyperspectral sensors are characterized by their high spectral resolution across a wide range of the electromagnetic spectrum, enabling the identification of chemical composition of the imaged target (rock, soils or vegetation). Hyperspectral sensors record reflected electromagnetic energy from the Earth surface across the electromagnetic spectrum extending from the visible wavelength region through the nearinfrared and mid-infrared region $(0.3 \mu \mathrm{m}$ to $2.5 \mu \mathrm{m}$ ) in tens to hundreds of narrow (in the order of $10 \mathrm{~nm}$ ) contiguous bands. Such narrow bandwidths results in an almost continuous and detailed spectral response for each pixel providing accurate and precise information about its constituents and is clearly an advantage over multispectral imaging. The high spectral resolution of a hyperspectral sensor allows us to capture small deviations in the spectral response of the materials thus aiding in their identification.

Numerous studies in recent years have shown relatively high correlations between soil reflectance and certain physical and chemical properties of soils. It has also been noted that the environmental conditions under which soils have been formed affect soil reflectance. If these relationships among soil reflectance and chemical and physical properties can be established quantitatively and definitively for given environmental conditions, the capacity to extract useful soils information from sensor data obtained by current and future earth observation satellite systems will be greatly enhanced. In recent years more emphasis has been given for launching hyperspectral satellites for detailed characterization of the land surface features at regional scale. ${ }^{20,21}$

As against the traditional method of soil sampling and laboratory analysis of soils, image or reflectance based remote sensing is an efficient, fast and economically sustainable way to detect spatial difference in crop and soil conditions within field. It offers the potential for identifying fine-scale spatial patterns in soil properties across a field and optimizing soil sampling strategies to quantify these patterns. Several soil properties, namely, surface condition, particle size, organic matter, soil colour, moisture content, iron and iron oxide content and mineralogy have been found to affect their spectral behavior. 
Table.1 Types of soil survey

\begin{tabular}{|c|c|c|c|}
\hline & $\begin{array}{l}\text { Reconnaissance } \\
\text { survey (Low } \\
\text { intensity / small } \\
\text { scale mapping) }\end{array}$ & $\begin{array}{lr}\text { Detailed } & \text { survey } \\
\text { (High intensity / } \\
\text { large } & \text { scale } \\
\text { mapping) } & \end{array}$ & $\begin{array}{l}\text { Detailed } \\
\text { Reconnaissance survey } \\
\text { (Medium intensity) }\end{array}$ \\
\hline Base map & $\begin{array}{l}\text { SOI toposheets } \\
1: 50,000\end{array}$ & $\begin{array}{l}\text { Village maps / } \\
1: 4000 / 1: 8000\end{array}$ & $\begin{array}{l}\text { This combines both } \\
\text { reconnaissance and } \\
\text { detailed soil surveys. }\end{array}$ \\
\hline Soil profile & 3 to $6 \mathrm{~km}$ & 640 & \multirow{4}{*}{$\begin{array}{l}\text { Reconnaissance survey } \\
\text { is conducted } \\
\text { throughout the project } \\
\text { area and detailed } \\
\text { survey is conducted in } \\
\text { intensively cultivation } \\
\text { areas. }\end{array}$} \\
\hline $\begin{array}{l}\text { Soil observation } \\
\text { (through auger) }\end{array}$ & $1 / 4 \mathrm{~km}$ to $1 \mathrm{~km}$ & $1 / 4$ to $1 / 2 \mathrm{~km}$ & \\
\hline Mapping unit & $\begin{array}{l}\text { Soil series / soil } \\
\text { association }^{1} / \text { soil } \\
\text { complex }^{2}\end{array}$ & $\begin{array}{l}\text { Types }{ }^{3} \text { and Phases }{ }^{4} \\
\text { of soil series }\end{array}$ & \\
\hline Level of mapping & Taluk/district & Village/ block & \\
\hline
\end{tabular}

${ }^{1}$ Soil association consists of two or three soil series

${ }^{2}$ Soil compiled consists of more than 3 soil series

${ }^{3}$ Type means surface texture'

${ }^{4}$ Phase includes solum depth, slope, erosion, gravelliness, stoniness, salinity and alkalinity classes

Table.2 Horizon wise Analytical properties

\begin{tabular}{|r|l|l|l|}
\hline S.No & Physical & Chemical & Exchangeable \\
\hline $\mathbf{1}$ & Particle size fractions & $\mathrm{pH}$ & CEC \\
\hline $\mathbf{2}$ & Bulk density & $\mathrm{EC}$ & Ex-cations \\
\hline $\mathbf{3}$ & $\begin{array}{l}\text { Moisture capacity at Field } \\
\text { capacity and permenant wilting } \\
\text { point }\end{array}$ & $\begin{array}{l}\mathrm{CaCO}_{3}, \\
\text { Organic carbon, } \\
\text { Total Nitrogen }\end{array}$ & Ex-acidity \\
\hline
\end{tabular}

Table.3 Suggested methods for soil survey

\begin{tabular}{|l|l|l|l|}
\hline Maps & Scale & Base maps / RS tools & Level of use \\
\hline Explanatory maps & $1: 1 \mathrm{M} \&$ above & $\begin{array}{l}1: 1 \mathrm{M} \text { toposheets } \\
\text { satellite imageries }\end{array}$ & $\begin{array}{l}\text { State / Country } \\
\text { region }\end{array}$ \\
\hline Small scale maps & $1: 250,000$ scale & $\begin{array}{l}\text { Toposheets/ Satellite } \\
\text { imageries }\end{array}$ & $\begin{array}{l}\text { State / District/ } \\
\text { Agroclimatic region }\end{array}$ \\
\hline Medium scale & $1: 50,000$ scale & $\begin{array}{l}\text { Toposheets/Aerial } \\
\text { photographs / satellite } \\
\text { imageries }\end{array}$ & Taluk/ District \\
\hline Large scale & $\mathbf{1 : 1 0 , 0 0 0 ~ t o ~ 1 : ~ 2 5 , 0 0 0}$ & $\begin{array}{l}\text { Village maps/ Aerial } \\
\text { Photographs / PAN } \\
\text { merged LISS III } \\
\text { data Village/ Block }\end{array}$ \\
\hline
\end{tabular}



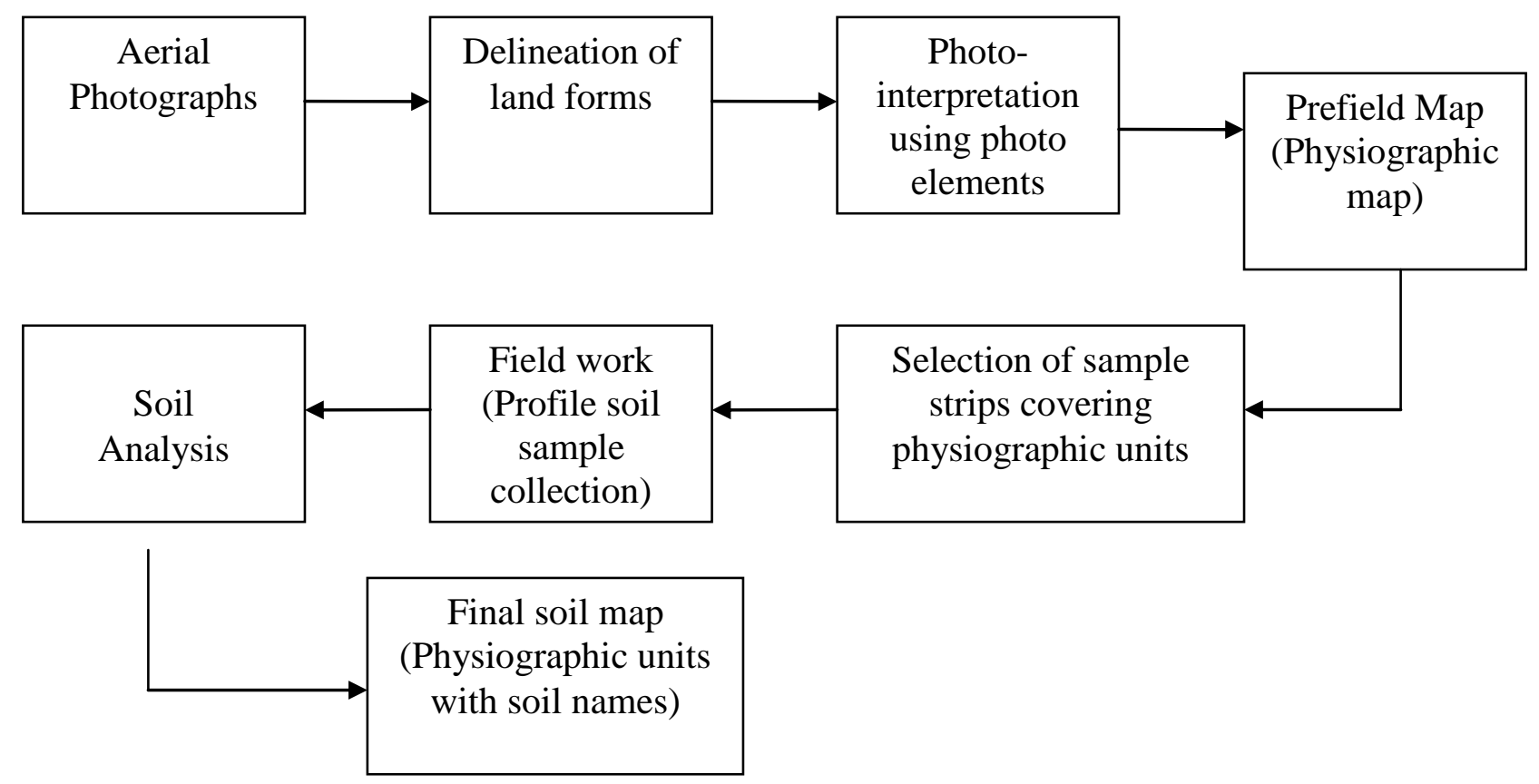

Figure.1 Methods of soil mapping using aerial photographs

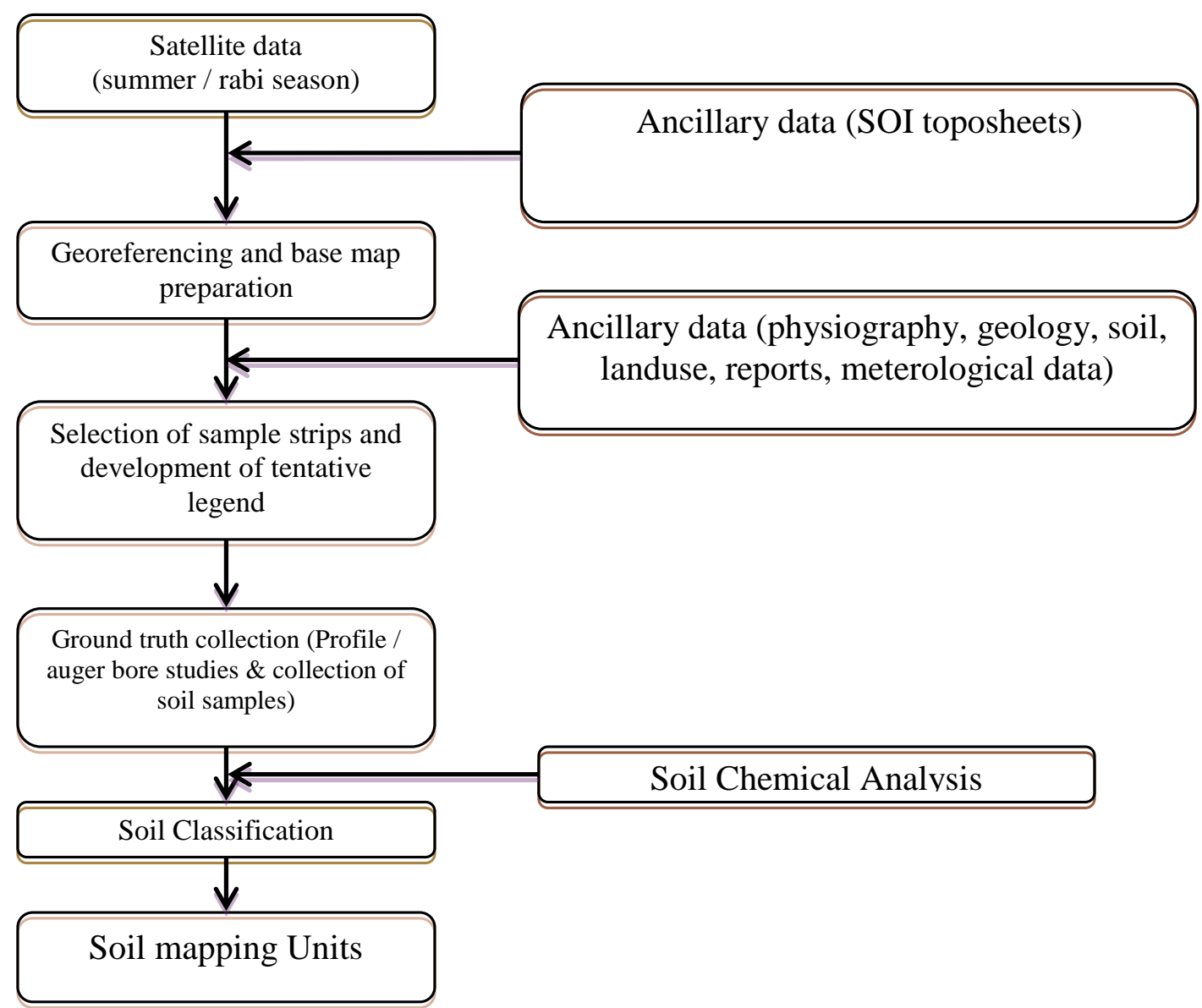

Figure.2 Visual interpretation of satellite imageries for soil mapping 
Remote sensing and GIS have emerged as effective tool in generating spatial information of natural resources. The planned and indiscriminate use of land has caused tremendous degradation of soils. Reliable inventory of soils and other resources are looking and therefore, need to be collected expeditiously. Remote sensing data has been established as tool insoil and other resource mapping.

Development of new generation of high spatial resolution, enhanced spectral coverage, revisit capabilities and stereo viewing have opened new vistas in various application areas. GIS technology is bringing about rapid changes in the spatial anlaysis and management of natural resources. GIS coupled with remote sensing GPS and computer technology is providing new methods for data acquisition, storage, processing analysis and modeling.

\section{Acknowledgements}

Authors are highly thankful to Agricultural College and Research Institute, Vazhavachanure, Tiruvannamalai, Tamil Nadu Agricultural University, Coimbatore, India for motivating to complete this review article.

\section{References}

1. Nageswara Rao, P. P. 2005. Applications of Remote Sensing and Geographical Indication System in Land Resources Management North Eastern Space Applications Centre, Umiam-793103, Meghalaya.

2. Seelan, S. K., Laguette, S., Casady, G. M., \& Seielstad, G. A., 2003. Remote sensing applications for precision agriculture: A learning community approach. Remote Sensing of Environment. 88, 157-169.
3. Steininger, M.K., 1996. Tropical secondary forest regrowth in the Amazon: age, area and change estimation with Thematic Mapper data. International Journal of Remote Sensing. 17, 9-27.

4. Melesse, A., and Wang, X. 2007. Impervious Surface Area Dynamics and Storm Runoff Response. Remote Sensing of Impervious Surfaces; CRC Press/Taylor and Francis, 19, 369-384.

5. Philipson, P., and Lindell, T. 2003. Can coral reefs be monitored from space? Ambio, 32, 586-593.

6. Arunkumar, V., Natarajan S., and Sivasamy., R. 2002. Characterisation and classification of soils of Lower Palar Manimuthar Watershed. Agropedology. 12: 97-103.

7. Arunkumar, V., Natarajan, S., and Sivasamy., R. 2004. Soil resource mapping of Vellamadai village, Coimbatore district using fused (IRS 1C LISS III and PAN merged) space borne multispectral data. Madras Agric. J. 91: 399-405.

8. Karale, R.L. 1992. Remote sensing with IRS 1A in soil studies: Developments, status and prospects. In: Natural Resourcecs Management A new Perspective. (ed.) R.L. Karale. National Natural Resources Management System (NNRMS), Department of Space, Govt. of India, Bangalore, pp. 128-143.

9. Kudrat, M., A.K. Tiwari, S.K. Saha and S.K. Bhan. 1992. Soil resource mapping using IRS 1A LISS II digital data - A case study of Khandi area adjacent to Chandigarh, India. Int. J. Rem. Sens., (13): 3287 - 3302.

10. FAO. 1988. Guidelines for soil description. FAO. Rome.

11. Zhang, L. 1994. A comparison of the efficiency of the three models to estimate water yield changes after 
forced catchment conversion, M.Sc. (Forest) Thesis, University of Melbourne, Australia.

12. Gopal Krishan, S., Kushwaha, P.S. and Velmurugan, A. 2009. Land Degradation Mapping in the Upper Catchment of River Tons J. Indian Soc. Remote Sens. 37:49-59.

13. Williams, J.R. 1975. Sediment yield prediction with Universal Equation using runoff energy factor. In: Present and prospective Technology for predicting sediment yields and sources, Agricultural Research Service, US Department of Agriculture. 244-252.

14. Morgan, R.P.C., Morgan, D.D.V, Finney, H.J.1984. A predictive model for the assessment of soil erosion risk. J. Agric. Eng. Res. 30, 245-253.

15. Lal, R. 2001. Soil degradation by erosion, Land degradation\& development, 12: 519-539

16. Spanner, M.A., Strahler, A.H. Estes, J.E., 1983. Soil loss prediction in a Geographic Information System Format. In Papers Selected for Presentation at the Seventeenth International Symposium on Remote Sensing of Environment. 89-102. 2-9
June 1982. Buenos Aires, Argentina. Ann Arbor, Mich.

17. Anonymous. 1970. Soil survey manual, IARI, New Delhi.

18. Saha, S.K., M, Kudrat and Bhan, S.K. . 1991. Erosional soil loss prediction using digital satellite data and USLE. IN: applications of Remote sensing in Asia and Oceania- environmental change monitoring, Asian association of Remote sensing, 369-372.

19. Patel, N.R., Suresh kumar, Prasad, J. and Pande.L.M. 2002. Soil erosion risk assessment and land use adjustment for soil conservation planning using remote sensing and GIS. Asian Journal of Geoinformatics 1(2): 47-55.

20. Sureshkumar and Sharma, S. 2005. Soil erosion risk assessment based on Morgan, Morgan and Finney model using Remote sensing and Geographic information system. Hydrology J., 28 (1-2): 47-58.

21. Kruse, F.A., Boardman, J.W. and Huntington, F.J. 2003. Comparison of airborne hyperspectral data and EO-1 Hyperion for mineral mapping. IEEE transactions on geosciences and remote sensing .41:1388 - 1400 .

\section{How to cite this article:}

Arunkumar. V., M. Pandiyan and Yuvaraj. M. 2020. A Review on Remote Sensing and GIS Applications in Soil Resource Management. Int.J.Curr.Microbiol.App.Sci. 9(05): 1063-1075. doi: https://doi.org/10.20546/ijcmas.2020.905.117 